\title{
УДК 338.48(477.87)
}

Мізюк Б. М.,

mizjuk.bohdan@gmail.com, ORCID ID: 0000-0002-6917-6351,

Researcher ID: F-9090-2019,

д.е.н., проф., завідувач кафедри туризму та готельно-ресторанної справи, Львівський торговельноекономічний університет, м. Львів

Трач B. O.,

vtrach70@gmail.com,

магістрантка, Львівський торговельно-економічний університет, м. Львів

\section{ФОРМУВАННЯ ІНФОРМАЦІЙНОЇ БАЗИ В СИСТЕМІ УПРАВЛІННЯ ГОТЕЛЬНОГО ПІДПРИЕМСТВА}

\begin{abstract}
Анотація. В роботі розглянуто особливості впровадження інформаційних технологій у систему управління організаціями, котрі надають готельні послуги. Встановлено, щуо в Украӥні використання сучасних інформаційних технологій стає засобом здійснення конкурентної боротьби у готельному бізнесі. Узагальнено роль інформаційних ресурсів як необхідної умови ефективного управління готельним підприємством. Проаналізовано чинники, які впливають на рівень розвитку $і$ запровадження інформаційних технологій у готелях. Виявлено $i$ запропоновано заходи з удосконалення системи управління готельним комплексом. Загальними особливостями у впровадженні інформаційних технологій у готелях є автоматизаџія процесів планування, обліку $і$ управління основними напрямками діяльності готельного комплексу. Метою даної статті було дослідження стану впровадження інформаційних технологій у системі управління організацією на прикладі діяльності готельного комплексу Fest Hotel у м. Львові. Обгрунтовано доиільність впровадження сучасних інформаційних технологій y готельних комплексах. Запропонована авторами інформаційна система для готельного комплексу Fest Hotel дозволила виключити з асортименту низькорентабельні послуги $і$ замінити їх новими, більш ефективними. Економічний ефект одержується також від надання послуг через Інтернет. У результаті використання $i$ впровадження автоматизованої інформаџійної системи знизилися постійні та змінні витрати операційної діяльності, зокрема на технічне обслуговування і поточний ремонт готельного комплексу, на утримання систем зв'язку, поліпшилася якість послуг виконуваних робіт і підвищилася кваліфікація працівників готельного комплексу. Розроблено план впровадження інформаційних технологій, які, за оцінкою авторів, будуть мати вагомий економічний ефект і сприяти підвищенню конкурентоспроможності готельних комплексів.
\end{abstract}

Ключові слова: готель, інформаційні технології, управління підприємством, інформаційні ресурси, модель IT, аналіз, економічний ефект.

Mizyuk B. M.,

mizjuk.bohdan@gmail.com, ORCID ID: 0000-0002-6917-6351,

Researcher ID: F-9090-2019,

Doctor of Economics, Professor, Head of the Department of Tourism and Hotel\& Restaurant Business, Lviv University of Trade and Economics, Lviv

Trach V. O.,

Master's degree student, Lviv University of Trade and Economics, Lviv

\section{FORMATION OF INFORMATION BASE IN THE MANAGEMENT SYSTEM OF A HOTEL ENTERPRISE}

\footnotetext{
Анотація. The article considers the peculiarities of the introduction of information technologies in the management system of organizations that provide hotel services. It is determined that in Ukraine the use of modern information technologies becomes a tool of competition in the hotel business. The role of information resources as a necessary condition for effective management of a hotel enterprise is generalized. The factors influencing the level of development and introduction of information technologies in hotels are analyzed. Measures to improve the management system of the hotel complex have been identified and proposed. Common features in the introduction of information technologies in hotels are the automation of planning, accounting and management of the main activities of the hotel complex. The purpose of this article was to study the state of implementation of information technologies in the management system of the organization on the example of the hotel complex Fest Hotel in the city of Lviv. The expediency of introduction of modern information technologies in hotel complexes is substantiated. The information system proposed by the authors
} 
for the Fest Hotel allowed to exclude from the range a lowly profitable services and replace them with new, more efficient ones. The economic effect is also obtained from the provision of services via the Internet. As a result of the use and implementation of the automated information system, fixed and variable operating costs have been reduced, in particular for maintenance and current repair of the hotel premises, maintenance of communication systems as well as quality of services and skills of employees have been improved. A plan for the introduction of information technologies has been developed, which, according to the authors, will have a significant economic effect and help increase the competitiveness of hotel complexes.

Key words: hotel, information technologies, enterprise's management, information resources, IT model, analysis, economic effect.

\section{JEL Classification: L10, L12 \\ DOI: https://doi.org/10.36477/2522-1205-2020-61-20}

Постановка проблеми. Можливості автоматизації обслуговування готельного комплексу мають комплексний характер і охоплюють усі процеси функціонування структури і взаємин із гостями. Донедавна українська готельна індустрія знаходилася в ізоляції від світових тенденцій розвитку. Але сьогодні переживає етап масштабної реорганізації 3 паперово-ручного методу роботи на застосування автоматизованих IT управління підприємством [1]. Для більшості готелів України (60\%) впровадження автоматизованих інформаційних технологій (AIT) управління є необхідним і вже стало реальним фактом, вкрай важливим для успішного розвитку бізнесу [6]. Як в усьому світі, так і в Україні використання сучасних АIT стає засобом здійснення конкурентної боротьби готелів. Найвідомішими фірмами, що пропонують комплексні програмні засоби автоматизації IT готелів, є: "InterHotel", "LodgingTouchLibica" (Jii6pa Інтернешнл), "IntellectService” (BecT Про), "UCS-UKR”, “Галактика”, “CITEK", "Екперт Солюшн”. Ці фірми пропонують свої програмні продукти і сервісне обслуговування [8].

Загальними особливостями у впровадженні IT в готелях $\epsilon$ автоматизація процесів планування, обліку і управління основними напрямками діяльності готельного комплексу. Тому загалом їх можна розглядати як інтегровану сукупність таких основних підсистем: управління фінансами, управління матеріальними потоками, управління обслуговуванням, управління якістю, управління персоналом, управління збутом, аналіз фінансів, собівартості, оборотних коштів, управління маркетингом [5].

Автоматизація процесів функціонування систем готельного комплексу дозволяє автоматизувати виконання щоденних завдань персоналу i керівництва підприємством. Цим досягається взаємозв'язок між різними службами готелю i підрозділами, підвищується ефективність, а також це дозволяє позбутися помилок у прийнятті управлінських рішень [3]. Багато завдань, наприклад прийом i розміщення великих груп гостей i застосування складних тарифних планів, стають легко здійсненними. Разом 3 цим керівництво одержує потужний інструмент контролю над станом готельного комплексу і фінансових потоків, а можливості зловживань персоналом скорочуються до мінімуму. Керівництво підприємства, одержуючи адекватні дані про стан справ на поточний момент і прогнози на майбутнє, має можливість приймати коректні, своєчасні і правильні управлінські рішення [4].

Аналіз останніх досліджень і публікацій. Дослідження щодо використання новітніх інформаційних технологій у діяльності підприємств туристичної сфери і туризмі в цілому здійснювали В. Гуляєв, І. Зорін, В. Квартальнов та інші. Однак дослідженню застосування інформаційних технологій в управлінні готельними комплексами присвячені зазвичай лише наукові статті або окремі розділи підручників та монографій [2]. Питаннями впровадження інформаційних систем займаються багато з дослідників інформаційного менеджменту, фахівців - практиків. Серед них - П. Друкер, Й. Масуда, С. Парінов, Л. В. Плескач та інші [7].

Постановка завдання. Метою даної роботи $\epsilon$ дослідження стану впровадження інформаційних технологій у системі управління організацією на прикладі діяльності готельного комплексу Fest Hotel у м. Львові.

Виклад основного матеріалу дослідження. Роль та значення інформаційних технологій у організації діяльності сучасних готельних комплексів постійно зростає. Необхідність їх запровадження обумовлена зростаючою конкуренцією на ринку готельно-ресторанних послуг та необхідністю вдосконалення інструментарію управління у цій сфері економічної діяльності. Ступінь автоматизації процесів діяльності готелів та ресторанів зростає 3 кожним роком, а необхідне для цього програмне забезпечення постійно вдосконалюється. Програмні продукти для готельно-ресторанних комплексів інтегруються 3 інформаційними системами інших учасників ринку для забезпечення максимальної ефективності функціонування у сучасних складних економічних умовах.

Нами були досліджені та проаналізовані особливості системи інформаційних технологій у готельному комплексі “Fest Hotel”. На рис. 1 показано концептуальну модель інформаційної технології готелю. 
Herald of Lviv University of Trade and Economics. Economic Sciences. № 61, 2020

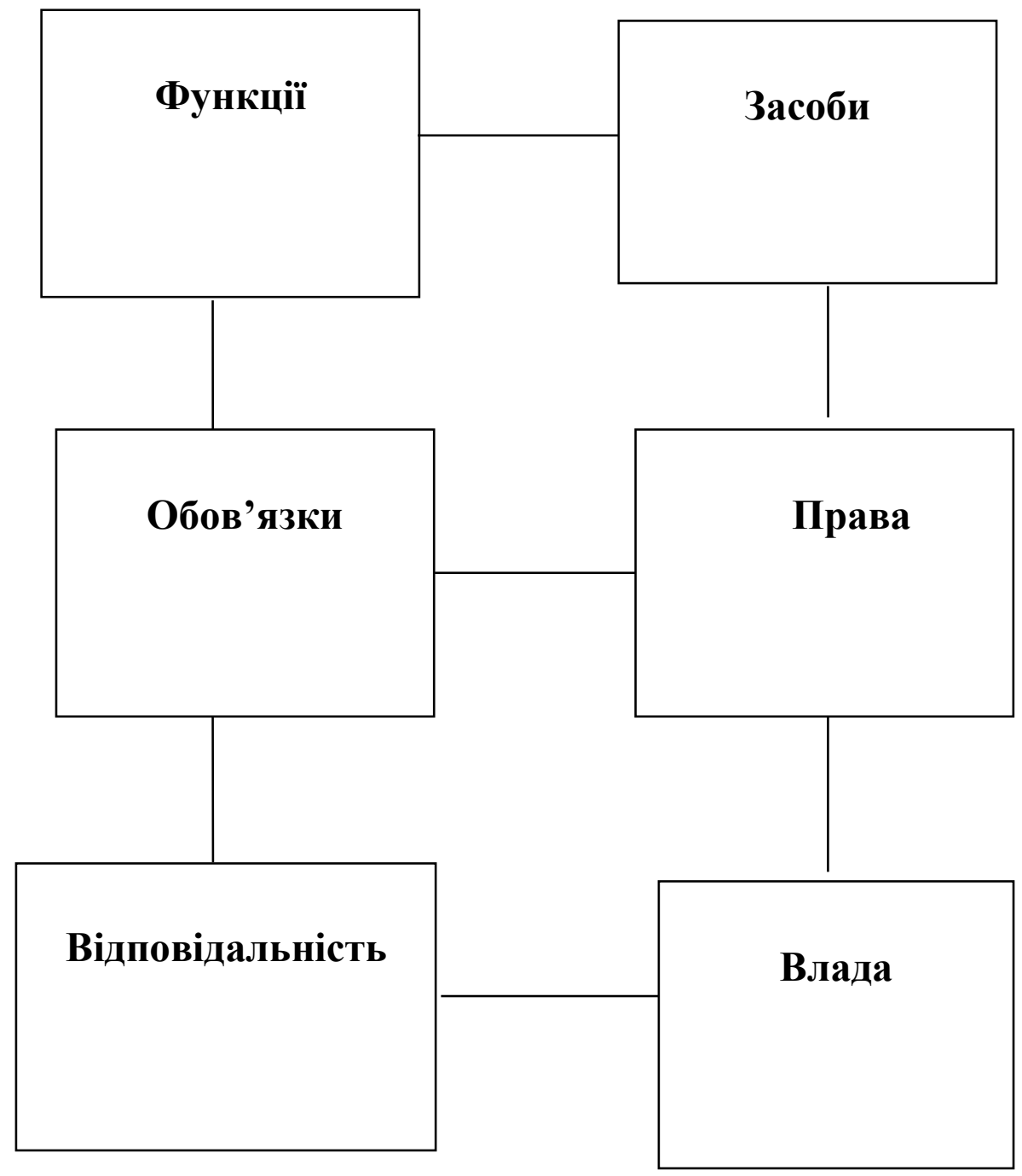

Рис. 1. Концептуальна модель інформаційної технології готелю

Для автоматизації виробничого процесу в готельному комплексі "Fest Hotel" вибрана і впроваджена автоматизована система управління готелем “SERVIO", яка забезпечує взаємозв'язану роботу всіх служб готелю для організації комплексного обслуговування й обліку побажань кожного клієнта, а також чітко дозволила розмежовувати функції персоналу за допомогою строго індивідуального доступу до системи [9].

Даний програмний продукт розроблено компанією "Expert Solution", адаптовано до специфіки ведення бізнесу в Україні. Розробник має висококваліфікований персонал, офіс консультаційної компанії знаходиться в м. Львові, що гарантує швидке виїзне обслуговування.

Компанія "Expert Solution" $€$ однією 3 провідних компаній українського ринку по системах автоматизації підприємств у сфері послуг. Компанія реалізує комплексні рішення з автоматизації й оптимізації ресторанного і готельного бізнеcy.

На рис. 2 показані IT-зв'язки в системі управління готельного комплексу.
Всі ці інформаційні потоки як окремі елементи інтегруються в єдиний інформаційний центр (ІЦ) готельного комплексу, що характеризується продуманим системним підходом. Це дає можливість для скорочення тривалості та оптимізації виробничого циклу, підвищення продуктивності у всіх ланках операційної системи готельного комплексу.

Інформаційна система для автоматизації управління служб готельного комплексу "Fest Hotel" будується в архітектурі “клієнт-сервер". На сервері знаходиться база даних, у якій міститься вся поточна та архівна інформація готельного комплексу, необхідна для роботи його служб. Вона має модульну структуру, що дозволяє конфігурувати i нарощувати систему на кожному робочому місці в кожній службі відповідно до їх функціональної спрямованості. Усі робочі місця взаємодіють із БД через локальну мережу готелю.

Розрахунок ефективності від впровадження інформаційних технологій у готельному комплексі "Fest Hotel" подано в табл. 1. 
Вісник Львівського торговельно-економічного університету. Економічні науки. №61, 2020

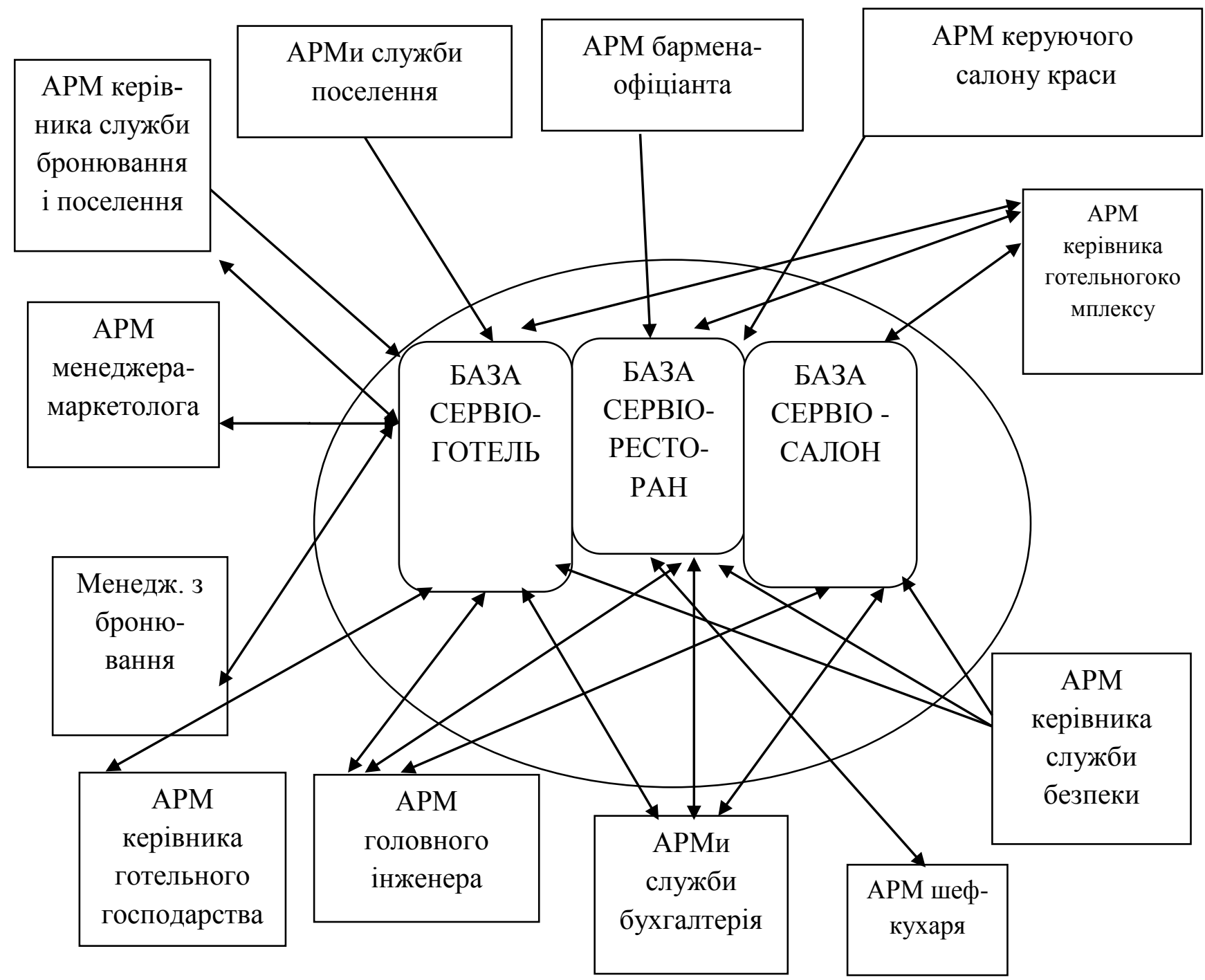

Рис. 2. IT-зв'язки в системі управління готельного комплексу

Таблиия 1

Перелік ресурсів для впровадження інформаційних технологій у готельному комплексі "Fest Ноtel"

\begin{tabular}{|c|c|c|c|c|c|}
\hline $\begin{array}{l}\text { № } \\
3 / \Pi \\
\end{array}$ & $\begin{array}{c}\text { Назва обладнання, матеріалів, робіт, } \\
\text { послуг } \\
\end{array}$ & $\begin{array}{l}\text { Одиниця } \\
\text { виміру }\end{array}$ & $\begin{array}{l}\text { Кіль- } \\
\text { кість }\end{array}$ & $\begin{array}{c}\text { Ціна за один. } \\
\text { виміру, грн }\end{array}$ & Сума, грн \\
\hline 1 & 2 & 3 & 4 & 5 & 6 \\
\hline 1 & $\begin{array}{l}\text { Програмне забезпечення 1C: } \\
\text { Підприємство } 8.2\end{array}$ & комплект & 1 & 33265,00 & 33265,00 \\
\hline 2 & П3 “Smart Accounting” & комплект & 1 & 137400,00 & 137400,00 \\
\hline 3 & П3 “Servio HMS” & ШТ. & 1 & 125000,00 & 125000,00 \\
\hline 4 & $\begin{array}{l}\text { П3 “Dial Audit” - тарифікація теле- } \\
\text { фонних розмов }\end{array}$ & шт. & 75 & 410,00 & 30750,00 \\
\hline 5 & Модуль “Заходи” & ШТ. & 1 & 25000,00 & 25000,00 \\
\hline 6 & Модуль “Покоївки" & ШТ. & 1 & 25000,00 & 25000,00 \\
\hline 7 & Інтерфейс із програмою тарифікації & ШТ. & 1 & 12500,00 & 12500,00 \\
\hline 8 & Інтерфейс із системою КД & ШТ. & 1 & 25000,00 & 25000,00 \\
\hline 9 & $\begin{array}{l}\text { Інтерфейс із фіскальним } \\
\text { реєстратором }\end{array}$ & шт. & 1 & 12500,00 & 12500,00 \\
\hline 10 & Інтерфейс із ресторанною системою & Шт. & 1 & 12500,00 & 12500,00 \\
\hline 11 & $\begin{array}{l}\text { Інтерфейс із бухгалтерськими } \\
\text { системами }\end{array}$ & шт. & 2 & 5500,00 & 11000,00 \\
\hline 12 & $\begin{array}{l}\text { Модуль бронювання SERVIO Reser- } \\
\text { vation }\end{array}$ & шт. & 1 & 25000,00 & 25000,00 \\
\hline 13 & Модуль “Резервування” & шт. & 1 & 12500,00 & 12500,00 \\
\hline 14 & Servio POS (ресторан, бар) & шт. & 2 & 10000,00 & 20000,00 \\
\hline
\end{tabular}


Herald of Lviv University of Trade and Economics. Economic Sciences. № 61, 2020

\begin{tabular}{|c|c|c|c|c|c|}
\hline \multicolumn{6}{|c|}{ Продовження табл. 1} \\
\hline 1 & 2 & 3 & 4 & 5 & 6 \\
\hline 15 & $\begin{array}{l}\text { Servio WorkDesk-модуль (система } \\
\text { керування і налаштування, звітність) }\end{array}$ & шт. & 1 & 15000,00 & 15000,00 \\
\hline 16 & Модуль “Дисконтна система” & шт. & 1 & 40000,00 & 40000,00 \\
\hline 17 & $\begin{array}{l}\text { Інтерфейс із фіскальним } \\
\text { реєстратором }\end{array}$ & шт. & 1 & 2500,00 & 2500,00 \\
\hline 18 & $\begin{array}{l}\text { Встановлення, налаштування } \\
\text { додаткових інтерфейсів }\end{array}$ & разів & 1 & 26635,00 & 26635,00 \\
\hline 19 & Налаштування сервера баз даних & разів & 1 & 22000,00 & 22000,00 \\
\hline 20 & $\begin{array}{l}\text { Налаштування робочого місця } \\
\text { користувача }\end{array}$ & разів & 3 & 2000,00 & 6000,00 \\
\hline 21 & $\begin{array}{l}\text { Наповнення бази даних (ввід прейс- } \\
\text { курантів, номерного фонду, кори- } \\
\text { стувачів, налаштування прав досту- } \\
\text { пу) }\end{array}$ & разів & 1 & 9000,00 & 9000,00 \\
\hline 22 & $\begin{array}{l}\text { Базове навчання по системі автома- } \\
\text { тизації для обслуговуючого персо- } \\
\text { налу }\end{array}$ & годин & 5 & 1000,00 & 5000,00 \\
\hline 23 & Курс консультацій персоналу & годин & 30 & 1000,00 & 30000,00 \\
\hline 24 & $\begin{array}{l}\text { Авторський нагляд при вводі в } \\
\text { експлуатацію }\end{array}$ & доба & 2 & 5000,00 & 10000,00 \\
\hline 25 & Авторський нагляд на об’єкті & разів & 1 & 5000,00 & 5000,00 \\
\hline & Всього ПЗ & & & & 677550,00 \\
\hline 26 & $\begin{array}{l}\text { Монтаж структурованих кабельних } \\
\text { мереж }\end{array}$ & комплект & 1 & 606590,00 & 606590,00 \\
\hline 27 & $\begin{array}{l}\text { Оргтехніка (комп’ютери, принтери, } \\
\text { сканери) }\end{array}$ & комплект & 1 & 538535,00 & 538535,00 \\
\hline & Разом & & & & 1822675,00 \\
\hline
\end{tabular}

Чистий приведений дохід проекту (NPV) при ставці дисконтування $11 \%$ річних і інтервалі планування 2 роки становить 433478, 15 грн. Враховуючи початкові інвестиції і грошовий потік по проекту, бачимо, що позитивна величина NPV підтверджує доцільність вкладення коштів у розглянутий проект.

$$
\begin{gathered}
N P V=\frac{1683430}{(1+0.11)}+\frac{1641800}{(1,11 * 1,11)}-1822675 \\
=433478,15 \text { грн. }
\end{gathered}
$$

Внутрішню норму доходності обчислюємо за формулою:

$$
I R R=\frac{433478,15}{1822675} \times 100 \%=23,7 \%
$$

Термін окупності проекту (РВ) характеризує період, за який кошторисну вартість проекту буде відшкодовано за рахунок рівномірного за роками нагромадження балансового прибутку.

$$
P B=\frac{1822675}{(1298950+1248180) / 2}=1,43 \text { років, }
$$

де 1822675 - сума інвестицій, грн;

$1298950+1248180=2547130-$ розрахунковий середній балансовий прибуток у рік, що буде отриманий у результаті здійснення проекту, грн.

Індекс дохідності (PI) показує рентабельність проекту і визначає, якою мірою зростає цінність підприємства в розрахунку на 1 грн інвестицій. Прийнятним результатом є показник, що дорівнює або перевищує 1 .

$$
P I=\frac{2667380,95}{1822675} \times 100 \%=1,46 \%
$$


Інтегральні показники проекту

\begin{tabular}{|c|l|c|c|}
\hline \multirow{2}{*}{ № } & \multicolumn{1}{|c|}{ Показник } & Значення & $\begin{array}{c}\text { Рекомендоване } \\
\text { значення }\end{array}$ \\
\hline 1 & Чистий приведений дохід, NPV, грн & 433478,15 & Більше 0 \\
\hline 2 & Внутрішня норма доходності, IRR, \% & 23,7 & Більше $11 \%$ \\
\hline 3 & Індекс прибутковості, РI & 1,46 & Більше 1 \\
\hline 4 & Термін окупності, РВ, рік & 1,43 & Менше 2 років \\
\hline 5 & Період розрахунку, міс. & 24 & \\
\hline
\end{tabular}

Аналізуючи основні показники інвестиційної привабливості проекту, а саме: чисту приведену вартість (NPV) і внутрішню норму рентабельності, - бачимо, що значення NPV додатне, а значення IRR більше, аніж відсотки за депозитом, що означає прийнятність даного проекту за цими критеріями.

Висновки і перспективи подалыших досліджень у даному напрямі. Проведений аналіз ефективності впровадження інформаційних технологій у систему управління готельного комплексу "Fest Hotel” дає змогу зробити висновок про доцільність реалізації цього проекту.

Інформаційна система готельного комплексу дозволила виключити 3 асортименту низькорентабельні послуги і замінити їх новими, більш ефективними. Економічний ефект одержується також від надання послуг через Інтернет.

У результаті використання і впровадження автоматизованої інформаційної системи знизилися постійні та змінні витрати операційної діяльності, зокрема на технічне обслуговування і поточний ремонт готельного комплексу, на утримання систем зв'язку, поліпшилася якість послуг виконуваних робіт і підвищилася кваліфікація працівників готельного комплексу.

У планах готельного комплексу - введення в експлуатацію системи автоматизованих роботів для прибирання, запуск програми “Розумний готель”.

\section{ЛІТЕРАТУРА}

1. Афанасьев С. В. Эффективность информационного обеспечения управления / Афанасьев С. В., Ярошенко В. Н. - М. : Экономика, 1987. - 111 с.

2. Бланк И. А. Инвестиционный менеджмент. Учебный курс. / Бланк И. А. - К. : Эльга-Н, Никацентр, 2001. - 448 с.

3. Глушков В. И. Введение в АСУ / Глушков В. И. - К. : Техника, 1974. - 320 с.

4. Грабова Н. М. Теорія бухгалтерського обліку / Грабова Н. М. - К. : Вища шк., 1973. - 344 с.

5. Гершегорин А. Т. Что такое АРМ бухгалтеpa? / Гершегорин А. Т. - М. : Финансы и статистика, 1988. - 95 с.
6. Джестон Дж. Управление бизнеспроцессами. Практическое руководство по успешной реализации проектов / Дж. Джестон, Й. Нелис. - СПб. : Символ-Плюс, 2008. - 456 с.

7. Денісова О. О. Інформаційні системи і технології в юридичній діяльності : навч. посібник / Денісова О. О. - К. : КНЕУ, 2004. - 307 с.

8. Коваленко О. О. Сучасні інформаційні системи - інвестиції в розвитку підприємства / Коваленко О. О. // Інвестиції: практика та досвід. - 2009. - № 2. - C. 10-13.

9. SERVIO hotel [Electr. resource]. - Available from: http://www.serviohotel.com/.

\section{REFERENCES}

1. Afanas'ev, S. V. and Yaroshenko, V. N. (1987), Effektyvnost' ynformatsyonnoho obespechenyia upravlenyia, Ekonomyka, M., 111 s.

2. Blank, Y. A. (2001), Ynvestytsyonnyj menedzhment. Uchebnyj kurs., El'ha-N, Nyka-tsentr, K., $448 \mathrm{~s}$.

3. Hlushkov, V. Y. (1974), Vvedenye v ASU, Tekhnyka, K., $320 \mathrm{~s}$.

4. Hrabova, N. M. (1973), Teoriia bukhhalters'koho obliku, Vyscha shk., K., 344 s.

5. Hershehoryn, A. T. (1988), Chto takoe ARM bukhhaltera?, Fynansy y statystyka, M., 95 s.

6. Dzheston Dzh. and Nelys J. (2008), Upravlenye byznes-protsessamy. Praktycheskoe rukovodstvo po uspeshnoj realyzatsyy proektov, Symvol-Plius, SPb., $456 \mathrm{~s}$.

7. Denisova, O. O. (2004), Informatsijni systemy i tekhnolohii v iurydychnij diial'nosti : navch. posibnyk, KNEU, K., 307 c.

8. Kovalenko, O. O. (2009), Suchasni informatsijni systemy - investytsii $\mathrm{v}$ rozvytku pidpryiemstva, Investytsii: praktyka ta dosvid, № 2, s. 10-13.

9. SERVIO hotel, available at: http://www.serviohotel.com/.

Стаття надійшла до редакиії 06 листопада $2020 \mathrm{p}$. 